\title{
Impact of Elicitation on Antioxidant and Potential Antihypertensive Properties of Lentil Sprouts
}

\author{
Elena Peñas ${ }^{1}$ - Rocío I. Limón ${ }^{1}$ - Cristina Martínez-Villaluenga ${ }^{1} \cdot$ Patrizia Restani $^{2}$. \\ Anne Pihlanto ${ }^{3}$ • Juana Frias ${ }^{1}$
}

(C) Springer Science+Business Media New York 2015

\begin{abstract}
The aim of this study was to investigate the application of elicitors $(500 \mu \mathrm{M}$ ascorbic acid, $50 \mu \mathrm{M}$ folic acid, $5 \mathrm{mM}$ glutamic acid and $50 \mathrm{ppm}$ chitosan in $5 \mathrm{mM}$ glutamic acid) during lentil germination up to 8 days as a strategy to increase germination rate and to enhance the accumulation of $\gamma$-aminobutyric acid (GABA) and phenolic compounds. The effect of elicitation on the protein profile and antioxidant and angiotensin I converting enzyme (ACE) inhibitory activities of sprouted lentils was also evaluated. The application of elicitors did not negatively affect the germination yield of lentils and no significant changes on the protein pattern of lentils germinated in the presence of elicitors were observed. Chitosan/glutamic acid increased by 1.6-fold the GABA content in lentil sprouts, whilst ascorbic and folic acids as well as chitosan/glutamic acid were highly effective to enhance the total content of phenolic compounds and the antioxidant activity of sprouted lentils. All elicited lentil sprouts showed ability to inhibit ACE activity $\left(\mathrm{IC}_{50}: 9.5-11.9 \mu \mathrm{g}\right.$ peptides/ $\mathrm{mL}$ ). Therefore, elicitation can be considered a promising approach to improve the content of compounds with antioxidant and potential antihypertensive activities in lentil sprouts.
\end{abstract}

Juana Frias

frias@ictan.csic.es

1 Institute of Food Science, Technology and Nutrition (ICTAN-CSIC), Juan de la Cierva 3, 28006 Madrid, Spain

2 Dipartimento di Scienze Farmacologiche e Biomolecolari, Università degli Studi di Milano, via Balzaretti 9, 20133 Milan, Italy

3 Natural Resource Institute Finland (LUKE), New Business Opportunities, New Products, Services and Technology, Myllytie 1, FI-31600 Jokioinen, Finland
Keywords Lentils $\cdot$ Sprouts $\cdot$ Elicitation $\cdot$ Antioxidant activity $\cdot$ Antihypertensive compounds

$\begin{array}{ll}\text { Abbreviations } \\ \text { ACE } & \text { Angiotensin I converting enzyme } \\ \text { ANOVA } & \text { Analysis of variance } \\ \text { DAO } & \text { Diamine oxidase } \\ \text { d.w. } & \text { Dry weight } \\ \text { GABA } & \gamma \text {-aminobutyric acid } \\ \text { GAD } & \text { Glutamate decarboxylase } \\ \text { GAE } & \text { Gallic acid equivalents } \\ \text { HPLC } & \text { High-performance liquid chromatography } \\ \text { kDa } & \text { Kilodalton } \\ \text { ORAC } & \text { Oxygen radical absorbance capacity } \\ \text { SDS- } & \text { Sodium dodecyl polyacrylamide gel } \\ \text { PAGE } & \text { electrophoresis } \\ \text { TE } & \text { Trolox equivalents } \\ \text { TPC } & \text { Total phenolic compounds }\end{array}$

\section{Introduction}

Hypertension is a global public health issue that accounts for 9.4 million deaths worldwide every year and is a major risk factor for the development of cardiovascular diseases [1]. The incidence of hypertension is expected to continue increasing in the next years and, therefore, World Health Organization emphasizes the importance of healthy dietary habits as a means of reducing the hypertension incidence and, consequently, the burden of hypertension on healthcare system [2].

A number of clinical studies have shown that regular consumption of legumes is associated with reduced risk of hypertension [3]. These beneficial effects may be attributed to their complex mixture of bioactive phytochemicals. Previous studies 
have shown that phytochemicals of legumes can be increased after germination, suggesting that legume sprouts may provide desirable health benefits beyond basic nutrition. In this sense, the improvement of the antioxidant activity of legumes during germination due to an increased content of polyphenols and vitamin $C$ has been reported by several authors [4-6]. Germination also improved the levels of GABA [7], a compound involved in the regulation of blood pressure [8], and promoted the liberation of bioactive peptides in diverse legumes [9]. The consumption of legume sprouts is, therefore, highly recommended and they are becoming increasingly popular as natural, low-fat and healthy foods. Lentils are an excellent vegetable material for obtaining sprouts since they have large protein concentration (20-40\%) [10], and higher polyphenol content than other legumes [11]. Moreover, lentils are good sources of dietary fiber, minerals and vitamins [12].

The application of chemical elicitors during germination is a booming cost-effective approach to enhance the nutritional quality and the phytochemical content of plants [13]. However, little has been reported about the application of chemical elicitors or precursors of GABA and phenolic compounds to enhance the nutritional and nutraceutical properties of legume sprouts. For instance, some studies have shown that the addition of polyphenol precursors and $\mathrm{H}_{2} \mathrm{O}_{2}$ as well as ascorbic and folic acid solutions improved the content of phenolic compounds and antioxidant activity of lentil, pea and fava bean sprouts [14-18], whilst glutamic acid feeding promoted the accumulation of GABA and phenolic compounds in germinated kidney beans [19]. Other studies supported the role of chitosan in stimulating the growth and productivity of soybean sprouts, as well as their vitamin $C$ content $[20,21]$. So far, the influence of elicitation on cardiovascular healthpromoting properties of lentil sprouts has not been examined. Therefore, the objective of this study was to evaluate the feasibility of elicitation with ascorbic and folic acids as well as with glutamic acid, alone or in combination with chitosan, to promote the accumulation of bioactive compounds involved in the prevention of hypertension (total phenolic compounds and GABA), the antioxidant activity of lentil sprouts and their ACE inhibitory activity after simulated gastrointestinal digestion. This study will provide useful information for the selection of elicitation treatments during germination to improve the vascular health-promoting properties of lentil sprouts, fostering their potential value as natural foods.

\section{Materials and Methods}

Plant Material Lentil seeds (Lens culinaris var. castellana) were supplied by Semillas Iglesias S. A. (Salamanca, Spain). Seeds were stored in polyethylene containers at $4{ }^{\circ} \mathrm{C}$ until germination.
Elicitor Solutions Five hundred $\mu \mathrm{M}$ ascorbic acid, $50 \mu \mathrm{M}$ folic acid, $5 \mathrm{mM}$ glutamic acid, and $50 \mathrm{ppm}$ low-molecular weight (LMW) chitosan in $5 \mathrm{mM}$ glutamic acid were used as elicitor solutions according to an earlier study [19]. Elicitors were purchased from Sigma-Aldrich (St. Louis, MO). All solutions were daily applied.

Germination Process Prior to germination, lentil seeds were soaked in distilled water for $6 \mathrm{~h}$. Hydrated seeds were placed in trays where a wet filter paper was extended, and were then covered. The trays were introduced into a germinator G-120 model (ASL Snijders International S.L., The Netherlands) and germination was conducted in darkness at $20^{\circ} \mathrm{C}$ for 8 days as previously described [22]. Seeds were irrigated daily with water (control experiment) or with fresh elicitor solutions. Three replications were performed for each germination treatment. Germination rate was calculated based on the number of seedlings from the total number of seeds. Sprouts were freeze-dried, milled and stored in vacuum bags at $-20^{\circ} \mathrm{C}$ until further analysis.

Total Protein Content Nitrogen content was determined by the Kjeldahl method, using a nitrogen analyzer (LECO Corp., St. Joseph, MI) [17]. A factor of 6.25 was used for the conversion of nitrogen to total protein content.

SDS-PAGE Protein Profile Flour from the obtained lentil sprouts was suspended in a sample buffer (containing $0.125 \mathrm{M}$ Tris- $\mathrm{HCl} \mathrm{pH}$ 6.8, $3.75 \%$ glycerol, $1 \%$ SDS and $2.5 \% \beta-$ mercaptoethanol) at a final concentration of $5 \mathrm{mg} / \mathrm{mL}$ and $10 \mu \mathrm{L}$ of each sample were loaded into the gel. SDS-PAGE was performed under reducing conditions as previously described [23]. A pre-stained molecular weight marker (broad range, Bio-Rad, Richmond, CA, USA) was run in parallel to the samples. Gels were dyed with Coomassie Brilliant Blue G-250.

GABA Content The extraction and quantification of GABA from lentil sprouts was conducted by HPLC [22]. Three GABA extractions were performed and HPLC analyses were carried out in duplicate. Results were expressed in $\mathrm{mg} / \mathrm{g}$ of dry weight (dw).

Total Phenolic Compounds (TPC) The content of TPC in elicited lentil sprouts was determined using Folin-Ciocalteu's phenol reagent. Briefly, $2 \mathrm{~g}$ of sprout flour were suspended in $10 \mathrm{~mL}$ of a solution containing HCl-methanol $(1 \%) /$ water $(80: 20, v / v)$ and the suspensions were kept for $16 \mathrm{~h}$ at room temperature with continuous stirring. TPC extraction and quantification was performed as described by Caceres et al. [24]. Results are expressed as mg of gallic acid equivalents (GAE)/g d.w. 
Antioxidant Activity The antioxidant activity was evaluated in the methanolic extracts obtained for TPC determination by using the oxygen radical absorbance capacity (ORAC-FL) method as previously reported [25]. Determinations were carried out in triplicate and results were expressed as $\mathrm{mg}$ of Trolox equivalents (TE)/ g dw.

Simulated Gastrointestinal Digestion In vitro gastrointestinal digestion of elicited sprouted lentils was performed using pepsin, trypsin and chymotrypsin (Sigma-Aldrich) simulating physiological conditions [19]. After digestion, samples were centrifuged at $10,000 \times g$ for $15 \mathrm{~min}$ at room temperature, subjected to ultrafiltration through membranes of $3 \mathrm{kDa}$ pore size (Millipore Corporation, MA, USA) and the permeates were collected for the analysis of ACE inhibitory activity.

ACE Inhibitory Activity The ACE inhibitory activity of in vitro-digested lentil sprouts and the $\mathrm{IC}_{50}$ values (concentration of sample that inhibits $50 \%$ of the ACE activity) were determined as in Torino et al. [25]. Results are expressed as $\mu \mathrm{g}$ peptides $/ \mathrm{mL}$.
Statistical Analysis Data were subjected to one-way ANOVA by using Statgraphics 5.0 software (Statistical Graphics Corp., Rockville, USA). Differences between samples were compared by using a Duncan's multiple-range test at $P \leq 0.05$ probability level.

\section{Results and Discussion}

Germination Rate Elicitation is a widely accepted agronomic strategy to enhance the germination rate and plant growth [26]. The germination percentage of lentils was differently affected by the elicitation treatments applied (Fig. 1a). Up to 6 days of germination, lentils elicited with ascorbic acid showed the largest germination yield (61-69\%), while those germinated with water (control) showed the lowest (46$57 \%$ ). However, the application of elicitors for 8 days did not result in any statistically significant differences of germination rate (73-78\% for all treatments). These results agree with those observed in kidney bean sprouts [19] but differ to those reported for peas [14], where elicitation with ascorbic or folic acid solutions caused higher germination rates than
Fig. 1 a Germination rate of lentil seeds in water and different elicitor solutions for 4, 6 and 8 days. b Content of proteins (bars) and GABA (black squares) of lentils germinated with water and different elicitor solutions for 8 days. Data indicate mean value \pm standard deviation of three independent experiments. Different lower case letters indicate significant differences $(P \leq 0.05)$ between elicitors at the same germination time. Data indicate mean value \pm standard deviation of three independent experiments. For GABA content, different lower case letters indicate significant differences $(P \leq 0.05)$; for protein content, different capital letters indicate significant differences $(P \leq$ $0.05 \%$ )

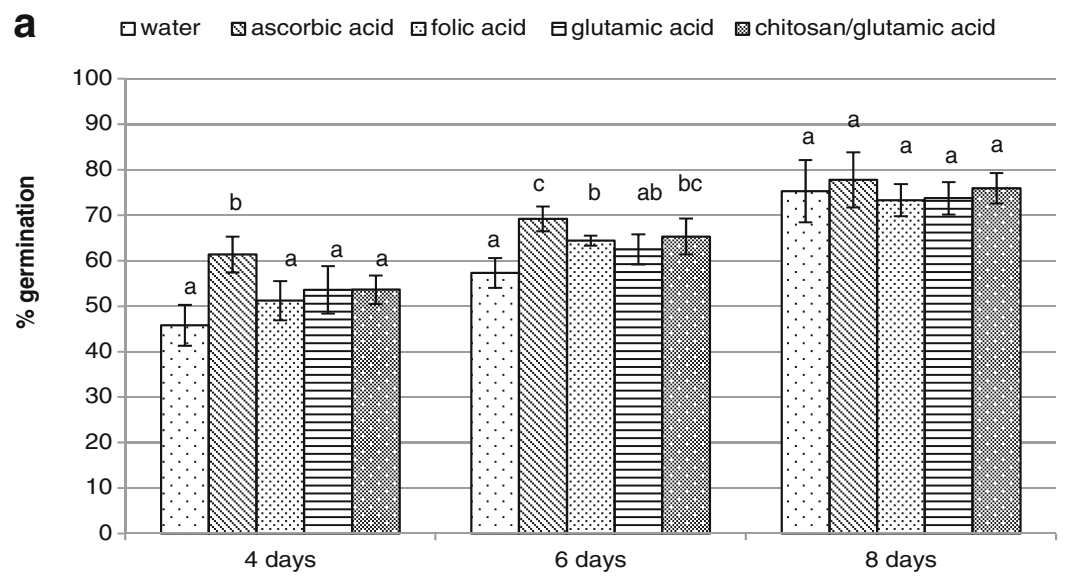

b

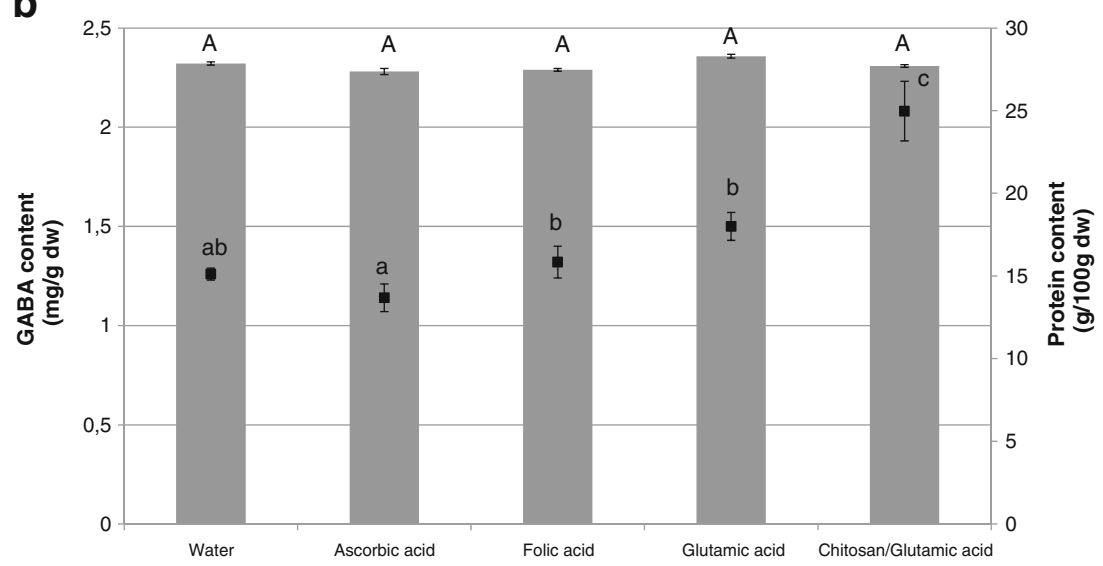


water. The different effect of elicitation observed in these studies can be attributed to the type of legume and the elicitor concentration used.

Taking into account the highest germination rate observed at 8 days, lentil sprouts obtained at this germination time were selected to evaluate the accumulation of phytochemicals.

Effect of Elicitation on Protein Content and Profile of Sprouted Lentils The total protein content in sprouted lentils was about $28 \%$ d.w., irrespectively of the type of elicitor solution applied during germination (Fig. 1b). To elucidate whether elicitation can lead to modifications of the sprouts protein profile, the SDS-PAGE pattern of sprouted lentils was studied (Fig. 2). As it can be observed, the qualitative electrophoretic profile of lentil sprouts was not notably influenced by the type of elicitor solution applied, although some quantitative differences in the protein bands intensity were found. All sprouted lentils showed a multitude of bands ranging from 9 to $95 \mathrm{kDa}$. Bands of $\sim 48$ and $61 \mathrm{kDa}$ corresponding to vicilin and convicilin, respectively, and two intense bands of 23 and $40 \mathrm{kDa}$ representing the basic and acidic subunits of $11 \mathrm{~S}$ globulin, respectively, were identified in the sprouts. The protein profile of elicited lentil sprouts observed in this work is in good agreement with that previously reported for lentil seeds [27], with some quantitative differences.

To our knowledge, there are no literature data on the effect of elicitation on the protein composition of lentil sprouts. The lack of modifications in sprouted seeds protein profile as consequence of elicitation has been recently observed in kidney bean [19]. Contrarily, Azooz et al. [28] observed the expression of new protein bands after priming fava bean seeds with $100 \mathrm{mg} / \mathrm{L}$ of ascorbic acid prior to their germination under salt stress. Similarly, Fercha et al. [29] reported changes in the abundance of metabolic proteins in wheat seeds elicited with

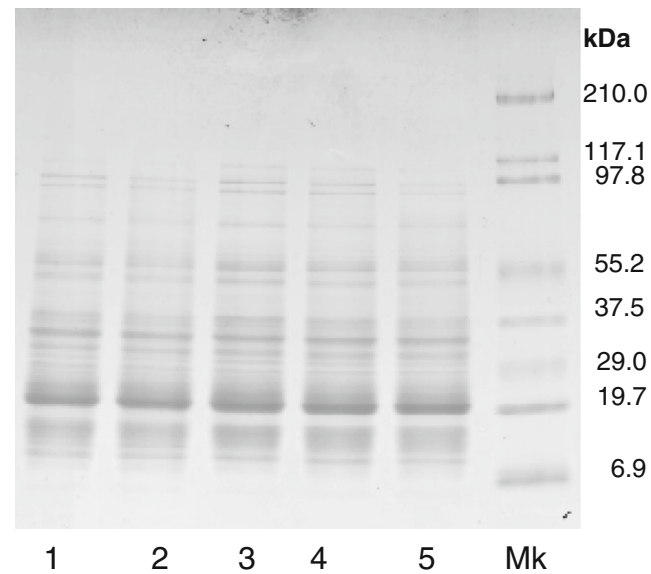

Fig. 2 SDS-PAGE profiles of lentils germinated with water (lane 1), ascorbic acid (lane 2), folic acid (lane 3), glutamic acid (lane 4) and chitosan/glutamic acid (lane 5) for 8 days. Mk molecular weight marker
$0.5 \mathrm{mmol} / \mathrm{L}$ of ascorbic acid during germination under salt stress. These findings suggest that the influence of elicitation on sprout protein composition is particularly pronounced under additional stress conditions. The present study was not performed under any additional stress condition and this fact could explain the absence of noticeable qualitative changes in the protein composition of elicited sprouted lentils. However, the synthesis/hydrolysis of proteins during lentil germination in the presence of elicitors cannot be ruled out, since small modifications in the protein pattern cannot be visualized by one-dimensional SDS-PAGE.

GABA Content in Elicited Lentil Sprouts Figure 1b depicts the GABA content in elicited sprouted lentils. The exogenous application of ascorbic, folic and glutamic acids during germination did not result in any statistically significant $(P>0.05)$ increase of GABA content in sprouted lentils compared with water $(1.2-1.5 \mathrm{mg} / \mathrm{g}$ d.w.). Contrarily, elicitation with chitosan/glutamic acid was revealed as highly effective to enhance GABA accumulation in lentil sprouts, increasing 1.6fold its concentration $(2.02 \mathrm{mg} / \mathrm{g} \mathrm{dw})$ compared with water. GABA is a non-protein amino acid with well documented hypotensive effects in animals and humans [8] that is primarily synthesized from glutamic acid by glutamate decarboxylase (GAD) [30]. An alternative source of GABA is the polyamine degradation pathway catalyzed by the diamine oxidase (DAO) [31]. It has been reported that glutamic acid stimulates the activity of GAD and DAO during legume germination [32]. Moreover, Oh [33] demonstrated that germination of brown rice in the presence of chitosan combined with glutamic acid resulted in greater GABA concentrations than using either solution alone. This author observed that chitosan can function as a plant elicitor, activating the mobilization and redistribution of calcium ions in plant cells, inducing the synthesis of calcium dependent enzymes, such as GAD. All these findings could explain the increase of GABA accumulation in lentils germinated in the presence of chitosan/glutamic acid.

Content of Total Phenolic Compounds (TPC) in Elicited Lentil Sprouts TPC concentration in sprouted lentils was differentially affected by the elicitor solutions applied (Fig. 3). Glutamic acid did not statistically increase $(P>0.05)$ the levels of TPC in lentil sprouts compared with water. However, the application of ascorbic acid, folic acid or chitosan/glutamic acid enhanced significantly $(P \leq 0.05)$ the phenolic content in sprouted lentils (3.6-3.9 mg GAE/g d.w.) and no significant differences $(P>0.05)$ among these elicitors were found. Our results are in agreement with those reported for sprouted peas, fava beans and kidney beans [14-16, 19]. The increased TPC concentration found in elicited sprouted lentils could be attributed to de novo synthesis of phenolic compounds since previous studies observed that chitosan and ascorbic and folic acids 
stimulate the pentose phosphate and phenylpropanoid pathways in legumes $[14,16]$.

Antioxidant Activity in Elicited Lentil Sprouts Elicitation enhanced significantly $(P \leq 0.05)$ the antioxidant activity of lentil sprouts, irrespectively of the elicitor used, compared to water (Fig. 3). Ascorbic acid, folic acid and chitosan/glutamic acid brought about the highest ORAC values in germinated lentils (12.3-13.5 mg TE/g d.w.) and no significant differences $(P>0.05)$ were found among them. These results mirrored those obtained for TPC, showing the great contribution of phenolic compounds to the antioxidant activity of lentil sprouts. This statement is supported by the positive correlation $(r=0.75)$ found between TPC content and ORAC values. Our results are consistent with previous studies indicating that abiotic elicitors increased the phenolic content and, consequently, the antioxidant activity of vegetable sprouts [14-16]. Ascorbic acid is a potent natural antioxidant that might also contribute to the enhancement of ORAC values in lentil sprouts treated with this elicitor, as it has been previously observed in pea sprouts [14]. On the other hand, glutamic acid improved the ORAC values but not the TPC in sprouted lentils. It can be hypothesized that glutamic acid could participate in the formation of some antioxidant compounds to maintain a balance of the redox homeostasis during germination. Additionally, glutamic acid might change the phenolic composition in sprouted lentils, increasing the content of those compounds with higher radical scavenging activity, as it has been previously showed in kidney beans [34].

\section{ACE Inhibitory Activity of In Vitro Digested Lentil}

Sprouts The ability of phytochemicals to inhibit ACE strongly depends on the retention of their structural integrity after gastrointestinal digestion. Additionally, during this physiological process new peptides with ACE inhibitory activity can be formed. Therefore, lentil sprouts were subjected to simulated gastrointestinal digestion prior to the ACE inhibitory analysis. The results, expressed as $\mathrm{IC}_{50}$ values, are presented in Table 1 .
Table 1 ACE-inhibitory activity (calculated as $\mathrm{IC}_{50}$ value) of lentils germinated with water and different elicitor solutions for 8 days

\begin{tabular}{lr}
\hline Germination solutions & $\mathrm{IC}_{50}(\mu \mathrm{g} / \mathrm{mL})$ \\
\hline Distilled water & $9.79 \pm 0.47^{\mathrm{a}}$ \\
Ascorbic acid & $9.53 \pm 0.43^{\mathrm{a}}$ \\
Folic acid & $11.48 \pm 0.54^{\mathrm{b}}$ \\
Glutamic acid & $11.70 \pm 0.57^{\mathrm{b}}$ \\
Chitosan/glutamic acid & $11.90 \pm 0.57^{\mathrm{b}}$ \\
\hline
\end{tabular}

Data indicate mean value \pm standard deviation of three independent experiments

Means with different superscript letters are significantly different $(P \leq 0.05)$

Elicitation with ascorbic led to similar ACE inhibitory activity of lentil sprouts than water $\left(\mathrm{IC}_{50}\right.$ value of $9.5 \mu \mathrm{g}$ peptides $/ \mathrm{mL}$ and $9.8 \mu \mathrm{g} / \mathrm{mL}$, respectively). In contrast, folic acid, glutamic acid and chitosan/glutamic acid decreased significantly $(P \leq$ $0.05)$ the ACE inhibitory efficacy of sprouted lentils $\left(\mathrm{IC}_{50}\right.$ : $11.5-11.9 \mu \mathrm{g}$ peptides $/ \mathrm{mL}$ ). The $\mathrm{IC}_{50}$ values obtained for all digested lentil sprouts $(9.5-11.9 \mu \mathrm{g} / \mathrm{mL})$ are in the range of those found for heat-treated lentils subjected to in vitro gastric digestion [35], and they are lower than those reported for hydrolysates produced from green and red lentils using different proteases (440-595 $\mu \mathrm{g} / \mathrm{mL}$ ) [36]. Many polyphenols, such as flavonoids and anthocyanins, and legume-derived peptides can act as ACE inhibitors [37, 38], and can contribute to the high ACE inhibitory activity observed in lentil sprouts.

\section{Conclusions}

This study shows that elicitation is a feasible approach to improve the phytochemical composition of sprouted lentils. All elicitors assayed markedly improved the antioxidant activity of lentil sprouts compared with water. Ascorbic and folic acids, as well as chitosan/glutamic acid significantly increased the TPC content in sprouted lentils. Chitosan/glutamic acid was the most effective treatment to enhance the GABA
Fig. 3 Total phenolic compounds (TPC) content (bars) and antioxidant activity (black squares) of lentils germinated with water and different elicitor solutions for 8 days. Data indicate mean value \pm standard deviation of three independent experiments. For TPC content, different lower case letters indicate significant differences $(P \leq 0.05)$; for antioxidant activity, different capital letters indicate significant differences $(P \leq 0.05)$

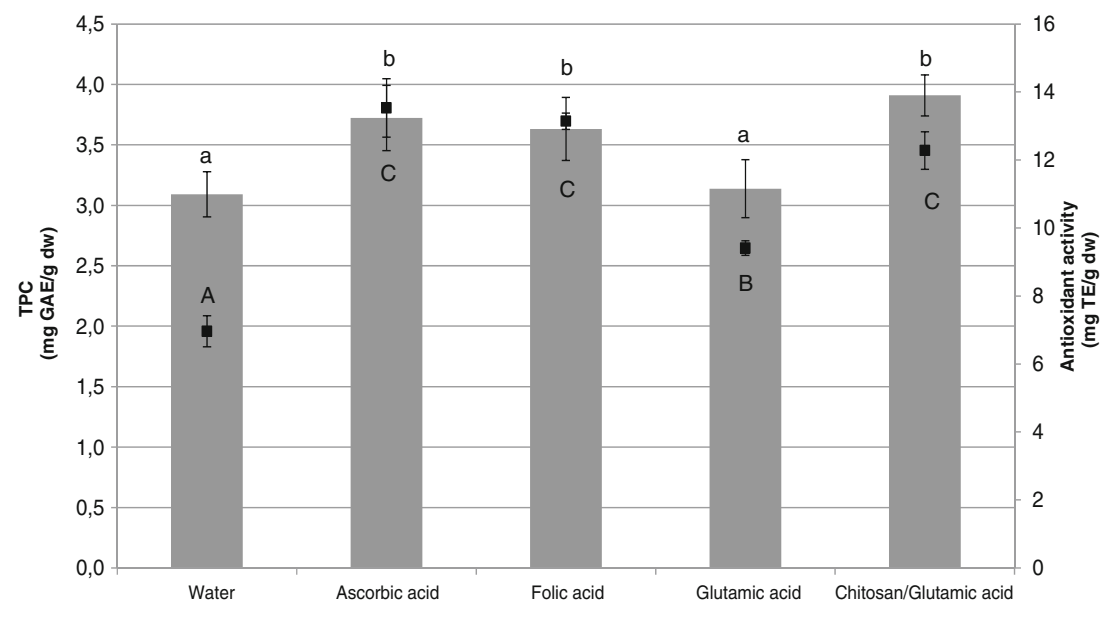


content in sprouted lentils. These findings provide interesting insights for the production of legume sprouts with potential antioxidant and antihypertensive properties.

Acknowledgments This work was cofounded by Ministerio de Economía y Competitividad (Spain) through the project AGL201016310 and the European Union through FEDER programme. E. Peñas in indebted to Spanish "Ramón y Cajal" Programme for financial support and R.I. Limón to CSIC and European Social Fund providing a PhD fellowship.

\section{Compliance with Ethical Standards}

Conflict of Interest The authors declare that they have no relevant conflicts of interest.

\section{References}

1. World Health Organization (2013) A global brief of hypertension. Silent killer, global public health crisis. Document number: WHO/ $\mathrm{DCO} / \mathrm{WHD} / 2013.2$

2. Nichols M, Townsend N, Luengo-Fernandez R, Leal J, Gray A, Scarborough P, Rayner M (2012) European Cardiovascular Disease Statistics 2012. European Heart Network, Brussels, European Society of Cardiology, Sophia Antipolis

3. Sacks FM, Svetkey LP, Vollmer WM, Appel LJ, Bray GA, Harsha D, Obarzanek E, Conlin PR, Miller ER, Simons-Morton DG, Karanja N, Lin PH (2001) Effects on blood pressure of reduced dietary sodium and the dietary approaches to stop hypertension (DASH) diet. N Eng1 J Med 344:3-10. doi:10.1056/ NEJM200101043440101

4. Dikshit M, Ghadle M (2003) Effect of sprouting on nutrients, antinutrients and in vitro digestibility of the MACS-13 soybean variety. Plant Foods Hum Nutr 58:1-11. doi:10.1023/B:QUAL. $0000040357.70606 .4 \mathrm{c}$

5. Rumiyati JV, James AP (2013) Total phenolic and phytosterol compounds and the radical scavenging activity of germinated Australian sweet lupin flour. Plant Foods Hum Nutr 68:352-357. doi:10.1007/s11130-013-0377-6

6. Świeca M, Gawlik-Dziki U, Kowalczyk D, Złotek U (2012) Impact of germination time and type of illumination on the antioxidant compounds and antioxidant capacity of Lens culinaris sprouts. Sci Hortic 140:87-95. doi:10.1016/j.scienta.2012.04.005

7. Martinez-Villaluenga C, Kuo YH, Lambein F, Frias J, VidalValverde C (2006) Kinetics of free amino acids, free non-protein amino acids and trigonelline in soybean (Glycine max L.) and lupin (Lupinus angustifolius L.) sprouts. Eur Food Res Technol 224:177186. doi:10.1007/s00217-006-0300-6

8. Diana M, Quílez J, Rafecas M (2014) Gamma-aminobutyric acid as a bioactive compound in foods: a review. J Funct Foods 10:407420. doi:10.1016/j.jff.2014.07.004

9. Bamdad F, Dokhani S, Keramat J, Zareie R (2009) The impact of germination and in vitro digestion on the formation of angiotensin converting enzyme (ACE) inhibitory peptides from lentil proteins compared to whey proteins. Int J Biol Life Sci 5:52-62

10. Duranti M (2006) Grain legume proteins and nutraceutical properties. Fitoterapia 77:67-82. doi:10.1016/j.fitote.2005.11.008

11. Xu BJ, Yuan SH, Chang SKC (2007) Comparative analyses of phenolic composition, antioxidant capacity, and color of cool season legumes and other selected food legumes. J Food Sci 72: S159-S166. doi:10.1111/j.1750-3841.2006.00261.x

12. Faris MAE, Takruri HR, Issa AY (2013) Role of lentils (Lens culinaris L.) in human health and nutrition: a review. Mediterr J Nutr Metab 6:3-16. doi:10.1007/s12349-012-0109-8

13. Baenas N, García-Viguera C, Moreno DA (2014) Elicitation: a tool for enriching the bioactive composition of foods. Molecules 19: 13541-13563. doi:10.3390/molecules190913541

14. Burguieres E, McCue P, Kwon YI, Shetty K (2007) Effect of vitamin $\mathrm{C}$ and folic acid on seed vigour response and phenolic-linked antioxidant activity. Bioresour Technol 98:1393-1404. doi:10. 1016/j.biortech.2006.05.046

15. Burguieres E, McCue P, Kwon YI, Shetty K (2008) Health-related functionality of phenolic-enriched pea sprouts in relation to diabetes and hypertension management. J Food Biochem 32:3-14. doi:10. $1111 /$ j.1745-4514.2007.00164.x

16. Randhir R, Shetty K (2007) Elicitation of the proline-linked pentose phosphate pathway metabolites and antioxidant enzyme response by ascorbic acid in dark germinated fava bean sprouts. J Food Biochem 31:485-508. doi:10.1111/j.1745-4514.2007.00126.x

17. Świeca M, Sęczyk Ł, Gawlik-Dziki U (2014) Elicitation and precursor feeding as tools for the improvement of the phenolic content and antioxidant activity of lentil sprouts. Food Chem 161:288-295. doi:10.1016/j.foodchem.2014.04.012

18. Świeca M (2015) Production of ready-to-eat lentil sprouts with improved antioxidant capacity: optimization of elicitation conditions with hydrogen peroxide. Food Chem 180:219-226. doi:10. 1016/j.foodchem.2015.02.031

19. Limón RI, Peñas E, Martínez-Villaluenga C, Frias J (2014) Role of elicitation on the health-promoting properties of kidney bean sprouts. LWT- Food Sci Technol 56:328-334. doi:10.1016/j.lwt. 2013.12.014

20. Lee YS, Kim YH, Kim SB (2005) Changes in the respiration, growth, and vitamin $\mathrm{C}$ content of soybean sprouts in response to chitosan of different molecular weights. HortSci 40:1333-1335

21. No HK, Lee KS, Kim ID, Park MJ, Kim SD, Meyers SP (2003) Chitosan treatment affects yield, ascorbic acid content, and hardness of soybean sprouts. J Food Sci 68:680-685. doi:10.1111/j. 1365-2621.2003.tb05731.x

22. Fernandez-Orozco R, Frias J, Zielinski H, Piskula MK, Kozlowska H, Vidal-Valverde C (2008) Kinetic study of the antioxidant compounds and antioxidant capacity during germination of Vigna radiata cv. emmerald, Glycine max cv. jutro and Glycine max cv. merit. Food Chem 111:622-630. doi:10.1016/j.foodchem.2008.04. 028

23. Peñas E, Uberti F, di Lorenzo C, Ballabio C, Brandolini A, Restani $P$ (2014) Biochemical and immunochemical evidences supporting the inclusion of quinoa (Chenopodium quinoa Willd.) as a glutenfree ingredient. Plant Foods Hum Nutr 9:297-303. doi:10.1007/ s11130-014-0449-2

24. Caceres PJ, Martínez-Villaluenga C, Amigo L, Frias J (2014) Maximising the phytochemical content and antioxidant activity of Ecuadorian brown rice sprouts. Food Chem 152:407-414 doi: 10. 1016/j.foodchem.2013.11.156

25. Torino MI, Limon RI, Martinez-Villaluenga C, Makinen S, Pihlanto A, Vidal-Valverde C, Frias J (2013) Antioxidant and antihypertensive properties of liquid and solid state fermented lentils. Food Chem 136:1030-1037. doi:10.1016/j.foodchem.2012.09.015

26. Eskandari H (2013) Effects of priming technique on seed germination properties, emergence and field performance of crops: a review. Int J Agron Plant Prod 4:454-458, ISSN:2051-1914

27. Barbana C, Boye JI (2013) In vitro protein digestibility and physico-chemical properties of flours and protein concentrates from two varieties of lentil (Lens culinaris). Food Funct 4:310-321. doi: $10.1039 / \mathrm{c} 2$ fo30204g 
28. Azooz MM, Alzahrani AM, Yuoussef MM (2013) The potential role of seed priming with ascorbic acid and nicotinamide and their interactions to enhance salt tolerance in broad bean (Vicia faba L.). Aust J Crop Sci 7:291-2100, ISSN:1835-2707

29. Fercha A, Capriotti AL, Caruso G, Cavaliere C, Samperi R, Stampachiacchiere S, Laganà A (2014) Comparative analysis of metabolic proteome variation in ascorbate-primved and unprimed wheat seeds during germination under salt stress. J Proteome 108: 238-257. doi:10.1016/j.jprot.2014.04.040

30. Shelp BJ, Bozzo GG, Trobacher CP, Chiu G, Bajwa VS (2012) Strategies and tools for studying the metabolism and function of $\gamma$-aminobutyrate in plants. I. Pathway structure. Botany 90:651668. doi:10.1139/B2012-030

31. Xing SG, Jun YB, Hau ZW, Liang LY (2007) Higher accumulation of $\gamma$-aminobutyric acid induced by salt stress through stimulating the activity of diamine oxidases in Glycine $\max (\mathrm{L}$.) Merr. roots. Plant Physiol Biochem 45:560-566. doi:10.1016/j.plaphy.2007.05. 007

32. Yang R, Guo Q, Gu Z (2013) GABA shunt and polyamine degradation pathway on $\gamma$-aminobutyric acid accumulation in germinating fava bean (Vicia faba L.) under hypoxia. Food Chem 136:152159. doi:10.1016/j.foodchem. 2012.08 .008

33. Oh S-H (2003) Stimulation of $\gamma$-aminobutyric acid synthesis activity in brown rice by a chitosan/glutamic acid germination solution and calcium/calmodulin. J Biochem Mol Biol 36:319-325. doi:10. 5483/BMBRep.2003.36.3.319

34. Dueñas M, Martinez-Villaluenga C, Limón RI, Peñas E, Frías J (2015) Effect of germination and elicitation on phenolic composition and bioactivity of kidney beans. Food Res Int 70:55-63. doi: 10.1016/j.foodres.2015.01.018

35. Akilhoglu HG, Karakaya S (2009) Effects of heat treatment and in vitro digestion on the angiotensin converting enzyme inhibitory activity of some legume species. Eur Food Res Technol 229:915921. doi:10.1007/s00217-009-1133-x

36. Boschin G, Scigliuolo GM, Resta D, Arnoldi A (2014) ACEinhibitory activity of enzymatic protein hydrolysates from lupin and other legumes. Food Chem 145:34-40. doi:10.1016/j. foodchem.2013.07.076

37. Guerrero L, Castillo J, Quiñones M, Garcia-Vallvé S, Arola L, Pujadas G, Muguerza B (2012) Inhibition of angiotensinconverting enzyme activity by flavonoids: structure-activity relationship studies. PLoS One 7, e49493. doi:10.1371/journal.pone. 0049493

38. Garcia-Mora P, Peñas E, Frias J, Martínez-Villaluenga C (2014) Savinase, the most suitable enzyme for releasing peptides from lentils (Lens culinaris var. Castellana) protein concentrates with multifunctional properties. J Agric Food Chem 62:4166-4174. doi:10.1021/jf500849u 